\title{
IN MEMORY OF MAKHMUDZHAN PAIZAKHMETOVICH IRISMETOV
}

Visionary scientist, one of the oldest members of the A. B. Bekturov Institute of Chemical Sciences, Laureate of the State Prize of the Republic of Kazakhstan (RK), Honored Citizen of South-Kazakhstan Oblast, Veteran of Labor, Academician of the Academy of Engineering Sciences of the RK and the New York Academy of Sciences, Professor Makhmudzhan Paizakhmetovich Irismetov passed away on October 18, 2008.

M. P. Irismetov was one of the acknowledged specialists in organic chemistry, the chemistry of natural compounds, and fine organic synthesis. He succeeded and studied under Academicians M. I. Goryaev and G. A. Tolstikov.

A manager of Shymkent Chemical and Pharmaceutical Factory, student of Tashkent State University, Engineer of the Central Plant Laboratory, teacher of Kazakh Chemical Engineering Institute, and then graduate student of the Institute of Chemical Sciences of the National Academy of Sciences of the RK, Head of the Laboratory of Alkaloids, Chief Scientist of the Institute, and Advisor to the General Director of AO "Khimfarm" for Science and New Drug Development represent the career path of Professor Makhmudzhan Paisakhmetovich Irismetov.

The range of scientific interests of Prof. M. P. Irismetov is rather broad. It includes the isolation, structural study, stereochemistry, synthetic transformations, and reaction mechanisms of resinous, triterpene acids, steroidal saponins, glycoalkaloids, phytosterols and biological structure-activity relationships. Research on new original preparations with a broad spectrum of therapeutic action based on active components of licorice root and steroidal compounds of Solanum laciniatum (lacinulated nightshade) was conducted under his direction.

The intellectual contribution of M. P. Irismetov to the development of domestic science consists of the development, implementation, and commercialization into medical practice of ten new domestic drugs such as glyderinine, the sodium salt of 18-dehydroglycyrrhetic acid, biological additives bioslastilin, ruvimin, and " $2 \%$ ointment Glynatin", the industrial launch of which occurred at AO "Khimfarm" in Shymkent.

Collaboration with pharmacists and biologists of leading scientific centers of the CIS, e.g., Kirov Leningrad Military Medical Academy, Moscow Medical Institutes I and II, All-Union Dermatovenerologic Institute, Moscow Oblast Dermatological Institute, Kharkov Medical Institute, Scientific Research Institute of Oncology and Radiology of the Ministry of Health (MH) of the RK, Scientific Research Institute of Cardiology and Internal Medicine of the MH RK, and others, in addition to leaders of Shymkent and Bakinsk chemical plants was characteristic of the scientific activity of M. P. Irismetov in the search for and discovery of new drugs.

The research of Prof. M. P. Irismetov resulted in the publication of over 300 co-authored articles in international and RK scientific journals, 2 monographs, 22 patent applications, 5 patents, and 12 pre-patents of the RK. He directed the defense of 2 doctoral and 10 candidate dissertations. He was awarded the State Prize of the RK in the Area of Science, Technology, and Education in 2003 for his work "Development, discovery, and incorporation of new original domestic drugs from synthetic and natural resources of Kazakhstan."

The abundant scientific, inventive, and social activity of Prof. M. P. Irismetov was acknowledged by medals "Eren Enbegi Ushin" (2004), "Veteran of Labor," Jubilee Medal on the 100-th Birthday of V. I. Lenin, "USSR Inventor", Ministry Award of the Ministry of Education and Health of the RK "For achievements in the development of science in the RK," and others. He was a laureate of the Prize Akim YUKO "Baurmal" (2002). In 2005, he received the title "Honored Citizen of SouthKazakhstan Oblast."

In times when everything is changing, the loss of people such as Makhmudzhan Paizakhmetovich Irismetov is especially painful. He showed during his whole life how the country, institute, and team that he loved must be served. He always took a personal interest in the problems of the institute. Everyone who had the pleasure to know Makhmudzhan Paizakhmetovich and work with him experienced the magnanimous effect of his exceptional personality.

The shining memory of Makhmudzhan Paizakhmetovich Irismetov will forever remain in the memory of colleagues, scientists, and friends.

Translated from Khimiya Prirodnykh Soedinenii, No. 6, p. 669, November-December, 2008. 